\title{
MAIN CAUSES OF DIGGING MACHINE FAILURES AND WAYS OF THEIR ELIMINATION
}

\author{
Nuritdin Shukurov \\ Candidate of Technical Sciences, \\ Associate Professor, Department of Technical Support, \\ Academy of the Armed Forces of the Republic of Uzbekistan, \\ Uzbekistan, Tashkent \\ E-mail: dr.nuritdin@yandex.ru
}

Madamin Sarimsakov

Teacher,

Department of Technical Support,

Academy of the Armed Forces of the Republic of Uzbekistan,

Uzbekistan, Tashkent

\section{ОСНОВНЫЕ ПРИЧИНЫ ОТКАЗОВ ЗЕМЛЕРОЙНЫХ МАШИН И ПУТИ ИХ УСТРАНЕНИЯ}

\author{
Шукуров Нуритдин Рахимович \\ канд. техн. наук, доиент, \\ кафедра технического обеспечения, \\ Академия Вооруженных Сил Республики Узбекистан, \\ Республика Узбекистан, г. Ташкент \\ Саримсаков Мадамин Файзилвахобович \\ преподаватель, \\ кафедра технического обеспечения, \\ Академия Вооруженных Сил Республики Узбекистан, \\ Республика Узбекистан, г. Ташкент
}

\begin{abstract}
As you know, failure is understood as an event consisting in complete or partial loss of system performance. Failures can be structural, which are due to miscalculations and mistakes made at the design stage of the machine; technological, resulting from a violation of the manufacturing technology of the machine; operational, caused by violation of the rules for the operation of the machine.

The article analyzes the violation of the performance potential of earth-moving machines in terms of corrosion parameters. The types of corrosive effects that are most susceptible to structural materials used in the manufacture of earthmoving machines are considered.

\section{АННОТАЦИЯ}

Как известно, под отказом понимается событие, заключающееся в полной или частичной утрате работоспособности системы. Отказы могут быть конструкционными, которые обусловлены просчетами и ошибками, допущенными на стадии проектирования машины; технологическими, являющимися результатом нарушения технологии изготовления машины; эксплуатационными, вызванными нарушением правил эксплуатации машины.

В статье анализируется нарушение потенциала работоспособности землеройных машин по параметрам коррозии. Рассмотрены виды коррозионных воздействий, которым наиболее подвержены конструкционные материалы, используемые при изготовлении землеройных машин.
\end{abstract}

Keywords: structural failure, technological failure, hardening method, working body of the machine, wear, resource, reliability.

Ключевые слова: конструкционный отказ, технологический отказ, метод упрочнения, рабочий орган машины, износ, ресурс, надежность.

As you know, the share of failures caused by wear of parts accounts for about $80 \%$ of the total number of machine breakdowns. The working bodies of earthmoving machines are subjected to especially intense abrasive wear. The creation of a more wear-resistant cutting body for earthmoving machines and its protection from wear, as well as the development of ways to in-

Bibliographic description: Shukurov N., Sarimsakov M. Main causes of digging machine failures and ways of their elimination // Universum: технические науки : электрон. научн. журн. 2021. 5(86). URL: https://7universum.com/ru/tech/archive/item/11795 
crease its resource, are among the priority tasks of manufacturers and operators every year becoming more and more relevant [1].

Failures can be structural, which are due to miscalculations and mistakes made at the design stage of the machine; technological, resulting from a violation of the manufacturing technology of the machine; operational, caused by violation of the rules for the operation of the machine.

As we know, technological methods are divided into methods of volumetric and surface hardening. The methods of volumetric hardening of parts involves carrying out any technological operations, as a result of which the material in all working sections acquires increased antiwear properties [2].

The main reasons for failures of earth-moving machines are overloads, as a result of which the actual stresses arising in the parts of the machine exceed the permissible values (wrong choice of safety margins); destruction of welded joints due to fatigue stresses (incorrect design of welded joints, poor-quality performance); Corrosion-mechanical and abrasive wear of bearings, gear wheels, chain joints, working bodies of the machine, parts of hydraulic equipment (poor choice of materials, anti-corrosion coatings, lubricants, cleanliness class of rubbing surfaces and fit of parts, hardness of the surface layer of parts; design of sealing elements and the like).

A major challenge for wheeled earthmoving machines is extending the life of tires, which cost about $20 \%$ of the total cost of running the machine and double the cost of running the engine. At the same time, with an increase in the carrying capacity and dimensions of the machine, the cost of operating tires increases by $40 \ldots 50 \%$.

A characteristic feature of the tires of many earthmoving machines is heavy loads and relatively low travel speeds (compared to the speeds of transport vehicles). Such tires must have a high abrasion resistance.

The wear of cutting bodies in soils depends on their properties, abrasiveness, density, moisture and chemical activity, as well as the particle size. A certain role in the wear of cutting bodies is played by the load and speed during wear by the physical and mechanical properties of materials and geometric shapes [3].
It is important to improve the reliability of the hydraulic drives of earth-moving machines. It is believed that at a pressure of the working fluid above $30 \mathrm{MPa}$, the $85 \% \gamma$-resource of hydraulic pumps should not be less than 5000 hours. To ensure this, it is necessary to use wear-resistant materials, means of reliable sealing of the hydraulic system, and reliable filters.

The typical mode of operation of the gear drives of earthmoving machines is to frequently reverse the machine's travel and shift gears under load. To ensure the service life of gears of $5000 \ldots 8000 \mathrm{~h}$, high-quality heat treatment and carburizing of the gear teeth, the use of reliable seals in gearboxes is required.

At the design stage, the reliability of the machine is ensured by its rational layout solution, the correct choice of construction materials, the shape and profiles of parts and elements of the metal structure; the use of modern calculation methods when determining loads, strength parameters and service life of parts and assembly units [4].

There are still no generally accepted methods for calculating parts for wear. However, based on practical experience and research into the processes of wear and tear of parts, we can recommend very effective means of hardening machine parts.

For example, molecular-mechanical processes that cause the seizure of metals during friction, tearing of metal particles from the surface of one part and enveloping them onto another, lead to the appearance of scratches and scoring on the working surfaces (seizing). At the same time, as a means of hardening, it is required to increase the surface hardness of the rubbing pairs and create such temperature operating conditions under which the surface hardness does not decrease, as well as to prevent the rubbing pairs from working without lubrication.

And in case of corrosive processes accompanied by mechanical processes (corrosion-mechanical wear), it is necessary to apply a layer of metal of high hardness and weakly oxidized to the working surfaces of the parts. It also requires an increase in the class of surface cleanliness, elimination of uneven residual stresses, especially in a thin near-surface layer.

\section{References:}

1. Tool wear during earthmoving [Iznos instrumenta pri zemleroynykh rabotakh]. https://t-magazine.ru/pages/iznos/. (date of appeal [data obrashcheniya]: 16.05.2021).

2. Shamonov, B.Sh. Ways of increasing the wear resistance of the cutting bodies of earth-moving machines / B.Sh. Shamonov, N.R. Shukurov, M.F. Sarimsakov, A.A. Tavbaev // European science. -2020. -No. 5 (54). - p. 13 -16.

3. Shukurov R.U. Energy approach in the study of the process of wear of the working bodies of earth-moving machines / R.U. Shukurov, N.R. Shukurov, B.F. Khuzhanazarov // Young scientist. -2020. -No.16 (306). - P. 168-171.

4. Shukurov R.U. Increasing the capability of cutting elements of excavators under operation of NMMC / N.R. Shukurov, A.N. Ruzibaev, A.I. Umarov // European science. -2020. -№ 3(52). - P. 20-22. 